\title{
UPAYA MENINGKATKAN SIKAP POSITIF BELAJAR DAN KREATIVITAS ANAK USIA DINI MELALUI PEMBELAJARAN PROBLEM SOLVING DI RA AL ISRO BOGOR
}

\author{
Khuzaimah $^{1}$, Zainal Abidin Arief ${ }^{2}$, Sigit Wibowo ${ }^{3}$ \\ Raudatul Athfal Al Isro Bogor \\ khuzaimah230774@gmail.com
}

\begin{abstract}
Abstrak : Peneliti mengobservasi perilaku anak selama kegiatan dengan menggunakan instrumen berupa lembar observasi, wawancara dan catatan lapangan. Data hasil observasi wawancara dan catatan lapangan diolah dengan cara kuantitatif yaitu menghitung proses aktivitas pembelajaran anak dengan pembelajaran Problem Solving dan indikator pada kegiatan pembelajaran yang dilaksanakan, serta kualitatif untuk melengkapi data. Penelitian ini memberikan hasil bahwa pembelajaran Problem Solving mampu meningkatkan sikap positif belajar dan kreativitas anak usia dini. Hal tersebut dapat dilihat dari hasil aktivitas anak selama proses pembelajaran dengan pembelajaran Problem Solving yaitu siklus 1 rata-rata prosentase kreativitas anak 36\%, pada siklus 2 mengalami peningkatan menjadi $70 \%$ dan pada siklus 3 mengalami peningkatan sebesar $93 \%$. Penerapan model pembelajaran Problem Solving juga mampu meningkatkan sikap positif belajar pada anak usia dini, hal tersebut dapat dilihat dari hasil nilai rata-rata yang diperoleh pada setiap siklusnya Pada siklus 1 rata-rata prosentasenya nya yaitu $56 \%$. Pada siklus 2 rata-rata prosentasenya yaitu $69 \%$ dan pada siklus 3 rata rata prosentase nya yaitu $93 \%$. Berdasarkan hal tersebut, peneliti menyimpulkan bahwa pembelajaran Problem Solving dapat meningkatkan sikap positif belajar dan kreativitas pada anak usia dini.
\end{abstract}

Kata Kunci : anak usia dini, sikap positif belajar, pembelajaran problem solving

\section{A. PENDAHULUAN}

Pada dasarnya setiap anak, termasuk anak usia dini memiliki potensi yang berbeda. Potensi yang dimiliki anak itu perlu dikembangkan sejak dini. Perkembangan potensi yang dimiliki anak tergantung dari berbagai faktor antara lain bawaan (genetik) dan lingkungan, termasuk kesehatan dan gizi. Untuk mengoptimalkan potensi yang dimiliki anak maka lingkungan, pendidikan, kesehatan dan gizi harus saling mendukung. Anak yang mendapatkan gizi yang cukup akan tumbuh menjadi anak yang sehat.
Anak merupakan individu yang sangat unik yang memiliki karakteristik tersendiri sesuai dengan tahapan usianya. Oleh sebab itu, upaya upaya pengembangan anak usia dini hendaknya dilakukan melalui belajar sambil bermain, karena bermain merupakan kegiatan yang amat sangat menyenangkan bagi anak. Melalui kegiatan bermain, anak akan banyak memperoleh kesempatan untuk bereksplorasi, berkreasi, dan berinteraksi dengan lingkungannya sehingga dapat mengembangkan kecerdasan anak. 
Sebagaimana telah diatur dalam Peraturan Menteri Pendidikan dan Kebudayaan Republik Indonesia Nomor 137 Tahun 2014, tentang Standar Nasional Pendidikan Anak Usia Dini dan Peraturan Menteri Pendidikan dan Kebudayaan Republik Indonesia Nomor 146 Tahun 2014 tentang kurikulum 2013 untuk Anak Usia Dini salah satu aspek perkembangan yang harus dikembangkan sejak usia dini adalah aspek afektif.

Mengatasi masalah tersebut, guru harus melakukan inovasi agar kegiatan pembelajaran berjalan secara aktif, kreatif, efektif, inovatif dan menyenangkan serta tidak membosankan. Guru juga harus mampu melatih anak untuk menyelesaikan suatu permasalahan, sehingga anak dapat mengembangkan kemampuan berpikirnya untuk mengeluarkan pendapat, memahami, menganalisis dan menyelesaikan permasalahan. Berdasarkan temuan masalah di atas, maka peneliti tertarik untuk melakukan penelitian tentang Pembelajaran Problem Solving untuk anak usia dini dengan harapan adanya peningkatan sikap belajar dan kreativitas anak usia dini dan penelitian ini berjudul "Upaya Peningkatan Sikap Positif Belajar Dan Kreativitas Anak Usia Dini Melalui Pembelajaran Problem Solving Di RA Al Isro Bogor".

\section{Sikap Positif Belajar}

Sebelum melaksanakan
intervensi tindakan, pada awal penelitian dilakukan wawancara dan asessmen pra siklus dengan tujuan untuk mengetahui kondisi awal sikap positif belajar siswa kelompok B RA $\mathrm{Al}$ Isro. Berdasarkan hasil pengamatan dan wawancara yang diperoleh, perbedaan sikap positif belajar tiap- tiap anak disebabkan oleh berbagai faktor diantaranya kegiatan pembelajaran yang masih berpusat pada guru dan kurang menggali kreativitas anak dalam pembelajaran juga dikarenakan pola asuh orangtua. Bila ditinjau dari segi ekonomi keluarga rata-rata orang tua siswa RA Al Isro Bogor memiliki kemampuan yang cukup mapan, namun masalahnya ada pada perhatian orang tua. Bagi orangtuanya yang sibuk bekerja cenderung menyerahkan pengasuhan anak pada pembantu rumah tangga sehingga anak kurang mendapatkan perhatian dan stimulus dalam memecahkan masalah sederhana yang dijumpai dalam kehidupan sehari-hari. Sedangkan anak yang salah satu orangtuanya bekerja atau bekerja tapi tidak terlalu sibuk, biasanya mendapat perhatian lebih dari orang tua sehingga sikap positif belajar dan kreativitasnya berkembang cukup baik.

\section{Sikap Belajar}

Masalah sikap merupakan masalah yang sering muncul pada lapangan ilmu jiwa atau psikologi, baik dalam psikologi sosial, psikologi pendidikan, psikologi perkembangan, psikologi kepribadian dan psikologi lainnya. Dalam hal ini manusia menghadapi sesuatu masalah itu antara yang satu dengan yang lainnya mempunyai sikap yang berbeda. Walaupun masalah yang dihadapi sama, namun ketika manusia menghadapinya dengan sikap yang tidak sama, ada yang bersikap masalah itu baik dan ada yang bersikap masalah itu buruk.

Dalam buku "Evaluasi Pendidikan" karya WayanNurkancana dan Samartana, sikap dapat didefinisikan sebagai suatu predisposisi atau kecenderungan untuk 
melakukan suatu respon dengan caracara tertentu terhadap dunia sekitarnya, baik berupa individuindividu maupun obyek-obyek tertentu.

Sikap ini akan memberi arah suatu perbuatan atau suatu tindakan seseorang. Tapi dalam hal ini tidak berarti bahwa semua tindakan atau perbuatan seseorang itu sama dengan sikap yang ada padanya. Mungkin ada sesuatu tindakan atau perbuatan itu tidak sama dengan sikap yang sebenarnya.

Dari buku "Psikologi Pendidikan dengan Pendekatan Baru", sikap adalah gejala internal yang berdimensi efektif berupa kecenderungan untuk mereaksi atau merespon (response tendensy) dengan cara yang relatif tetap terhadap obyek orang, barang dan sebagainya, baik secara positif maupun negatif.

Menurut pengertian di atas, maka sikap ini ada yang bersifat positif dan ada pula yang bersifat negatif. Sikap siswa yang positif, umpamanya kecenderungan ujung tindakannya adalah memperhatikan, mendekati, menyenangi, mengharapkan obyek tertentu dan menerima. Adapun sikap positif ini, mengharapkan sesuatu yang diingini sesuai dengan obyek yang ada dan ia tidak akan menolak, selalu menerima. Sebaliknya sikap siswa yang negatif, kecenderungan tindakannya adalah tidak memperhatikan, menjauhi, membenci, tidak mengharapkan sesuatu yang diingini sesuai dengan obyek yang ada dan ia akan menolak. Semua itu dapat menimbulkan kesulitan belajar siswa tersebut. Adapun sikap negatif ini, tidak mengharapkan sesuatu yang diingini sesuai dengan obyek yang ada dan ia akan menolak dan tidak ingin menerima.

\section{Pengertian Belajar}

Menurut pengertian secara psikologis, Belajar merupakan suatu proses perubahan yaitu perubahan tingkah laku sebagai hasil dari interaksi dengan lingkungannya dalam memenuhi kebutuhan hidupnya. Belajar merupakan suatu perubahan tingkah laku, dimana perubahan itu dapat mengarah kepada tingkah laku yang lebih baik, tetapi juga ada kemungkinan mengarah kepada kemungkinan tingkah laku yang lebih buruk. Belajar merupakan suatu perubahan yang terjadi melalui pelatihan atau pengalaman; dalam arti perubahan-perubahan yang disebabkan oleh pertumbuhanatau kematangan tidak dianggap sebagai hasil belajar; seperti perubahanperubahan yang terjadi pada seorang bayi.

\section{Teori Belajar}

Teori belajar adalah konsepkonsep dan prinsipprinsip belajar yang bersifat teroritis dan telah teruji kebenarannya melalui eksperimen.Teori belajar itu berasal dari teori psikologis dan terutama menyangkut masalah situasi belajar.

Beberapa teori belajar diantaranya adalah sebagai berikut : a) Teori Conditioning (pavlov dan Watson) Menurut teori ini belajar itu adalah suatu proses perubahan yang terjadi karena adanya syarat-syarat (conditions) yang kemudian menimbulkan reaksi (response). Untuk menjadikan seseorang itu belajar haruslah kita memberikan syarat-syarat tertentu.Yang terpenting dalam belajar menurut teori conditioning ialah adanya latihanlatihan yang kontinu.Yang diutamakan dalam teori ini ialah hal belajar yang terjadi secara otomatis.13 b) Teori Systematic Behaviour (Hull) 
Clark C. Hull mengemukakan teorinya, yaitu bahwa suatu kebutuhan atau "keadaan terdorong" (oleh motif, tujuan, maksud aspirasi, ambisi) harus ada dalam diri seseorang yang belajar, sebelum suatu respon dapat diperkuat atas pengurangan kebutuhan itu.14 c) Teori Belajar Menurut Psikologi Gestalt Belajar menurut Gestaalt bukan hanya sekedar merupakan proses asosiasi antara stimulus-respon yang makin lama makin kuat karena adanya pelatihan-pelatihan atau ulangan-ulangan. Belajar menurut psikologi Gestalt terjadi jika ada pengertian (insight), Pengertian (insight) ini muncul apabila seseorang setelah beberapa saat mencoba memahami suatu masalah, tiba-tiba muncul adanya kejelasan, terlihat olehnya hubungan antara unsur-unsur yang satu dengan yang lain, kemudian dipahami sangkut-pautnya; dimengerti maknanya.

\section{Ciri-Ciri Sikap Belajar}

Sebagaimana telah di jelaskan bahwa sikap merupakan kecenderungan untuk bertindak sesuai dengan yang dihadapi obyek.Dengan demikian attitude (sikap) itu senantiasa terarahkan terhadap suatu obyek.Tidak ada sikap tanpa obyek. Sikap atau attitude adalah berbeda dengan motif, di mana kalau motif merupakan suatu pengertian yang melingkupi penggerak, alasan-alasan atau dorongan-dorongan dalam diri manusia yang menyebabkan ia berbuat sesuatu. Sedangkan sikap merupakan pandangan atau perasaan terhadap suatu obyek.

Adapun beberapa ciri-ciri sikap menurut Sarlito Wirawan Sarwono adalah sebagai berikut, yaitu : 1) Dalam sikap selalu terdapat hubungan subyek-subyek. Tidak ada sikap yang tanpa obyek-obyek, ini bisa berupa benda, orang, hukum, lembaga masyarakat dan sebagainya. 2) Sikap tidak dibawa sejak lahir, melainkan dipelajari dan dibentuk melalui pengalaman-pengalaman. 3) Karena sikap dipelajari, maka sikap dapat berubahubah sesuai dengan keadaan lingkungan di sekitar individu yang bersangkutan pada saat-saat yang berbeda-beda. 4) Dalam sikap tersangkut juga faktor motivasi dan perasaan. 5) Sikap tidak menghilang walaupun kebutuhan sudah dipenuhi. $216)$ Sikap tidak hanya satu macam saja, melainkan sangat bermacammacam sesuai dengan banyaknya obyek yang dapat menjadi perhatian orang yang bersangkutan.

Sedangkan menurut Gerungan Dipl, ciri-ciri attitude adalah sebagai berikut : a) Attitude bukan dibawa orang sejak ia dilahirkan, melainkan di bentuk atau dipelajarinya sepanjang perkembangan orang itu dalam hubungan dengan objeknya. b) Attitude itu dapat berubah-ubah, karena itu attitude dapat dipelajari orang atau sebaliknya, attitudeattitude itu dapat dipelajari, karena itu attitude-attitude dapat berubah pada orang-orang bila terdapat keadaankeadaan dan syarat-syarat tertentu yang mempermudah berubahnya attitude pada orang itu. c) Attitude itu tidak berdiri sendiri, tetapi senantiasa mengandung relasi tertentu terhadap suatu obyek. Dengan kata lain, attitude itu berbentuk dipelajari, atau berubah senantiasa berkenaan dengan suatu objek tertentu yang dapat dirumuskan dengan jelas. d) Objek attitude itu dapat merupakan satu hal tertentu, tetapi dapat juga merupakan kumpulan dari hal-hal tersebut. Jadi attitude itu dapat berkenaan dengan satu objek saja, tetapi juga berkenaan dengan sederetan objek-objek yang serupa. e) Attitude mempunyai segi- 
segi motivasi dan segi-segi perasaan. Sifat inilah yang membedakan attitude dari kecakapan-kecakapan atau pengetahuan - pengetahuan yang dimiliki orang.

\section{Macam-Macam Sikap Belajar}

Manusia itu tidak dilahirkan dengan sikap pandangan ataupun sikap perasaan tertentu, tetapi sikap-sikap tersebut di bentuk sepanjang perkembangan. Peranan sikap di dalam kehidupan manusia adalah sangat besar, sebab apabila sudah di bentuk pada diri manusia, maka sikapsikap itu akan turut menentukan cara-cara bertingkah laku terhadap obyek-obyek sikapnya. Adanya sikapsikap menyebabkan bertindak secara khas terhadap obyekobyeknya.

Maka dari itu sikap dibedabedakan dalam beberapa macam aturan lain yaitu sikap sosial dan sikap individu.

1) Sikap Sosial Dalam buku psikologi karya Gerungan. DiplPsych, attitude sosial pernah dirumuskan sebagai berikut :"Suatu attitude sosial dinyatakan oleh cara-cara kegiatan yang sama dan berulang-ulang terhadap obyek social.

2) Sikap individual Sikap individual adalah sikap yang khusus yang terdapat pada setiap satu-satu orang terhadap obyek- obyek yang menjadi perhatian orangorang yang bersangkutan saja.

\section{Kreativitas Anak}

James J.Gallagher dalam Yeni

Rachmawati mengatakan bahwa "kreativitas merupakan suatu proses mental yang di lakukan individu berupa gagasan atau produk baru atau mengombinasikan antara keduanya yang akhirnya akan melekat pada dirinya."
Dalam refrensi lain juga dijelaskan oleh SC. Utami Munandar bahwa kreativitas adalah kemampuan untuk membuat kombinasi baru berdasarkan data, informasi atau untur-unsur yang ada. Dalam hal ini biasanya orang mengartikan kreativitas sebagai daya cipta, sebagai kemampuan untuk menciptakan halhal baru.

\section{Ciri - ciri kreativitas anak}

Salah satu aspek penting dalam kreativitas adalah memahami ciricirinya. Upaya menciptakan iklim yang kondusif bagi perkembangan kreatifitas yang hanya mungkin dilakukan jika kita memahami terlebih dahulu sifat-sifat kemampuan kreatifitas dan lingkungan yang turut mempengaruhinya.

Menurut Utami Munandar menyebutkan bahwa ciri-ciri karakteristik kreativitas antara lain :

1) Senang mencari pengalaman baru

2) Memiliki keasyikan dalam mengerjakan tugas-tugas yang sulit

3) Memiliki inisiatif

4) Memiliki ketekunan yang tinggi

5) Cenderung kritis terhadap orang lain

6) Berani menyatakan pendapat

7) Selalu ingin tahu

8) Peka atau perasa

9) Energy dan ulet

10) Menyukai tugas-tugas yang majemuk

11) Percaya kepada diri sendiri

12) Mempunyai rasa humor

13) Memiliki rasa keindahan

14) Berwawasan masa depan dan penuh imajinasi.

\section{Potensi Kreativitas Pada Anak}

Melalui pandangan secara psikologi pada dasar nya setiap 
manusia telah di karuniai potensi sejak di lahirkan diatas muka bumi. Hal ini dapat kita lihat pada prilaku bayi ataupun anak yang secara alamiah gemar bertanya, gemar mencoba, gemar memperhatikan hal baru, gemar berkarya melalui benda apa saja yang ada dalam jangkauannya termasuk di dalamnya gemar berimajinasi.

Potensi kreativitas ini dapat kita lihat melalui keajaiban alamiah juga seorang bayi dalam mengeksplorasi apapun yang ada di sekitarnya. Secara alamiah juga seseorang bayi selalu ingin tahu serta antusias dalam menjelajahi dunia di sekitarnya. Sementara itu Devito dalam supriadi yang dikutip oleh Yeni Rachmawaty mengemukakan bahwa kreativitas merupakan suatu kemampuan yang dimiliki oleh setiap orang dengan tingkat yang berbeda - beda. Setiap orang lahir dengan potensi kreatif.

\section{Faktor - Faktor yang \\ Mempengaruhi Kreativitas}

Faktor yang mempengaruhi kreativitas anak ada dua macam, yaitu faktor yang menudukung dan faktor yang menghambat. Adapun faktorfaktor yang dapat mendukung kreativitas anak adalah sebagai berikut:

1) Situasi yang menghadirkan ketidaklengkapan serta keterbukaan

2) Situasi yang memungkinkan dan mendorong timbulnya banyak pertanyaan

3) Situasi yang dapat mendorong dalam rangka menghasilkan sesuatu

4) Situasi yang mendorong tanggung jawab dan kemandirian.

5) Kedwibahasaan yang kemungkinan untuk mengembangkan potensi kreativitas secara lebih luas karena akan memberikan pandangan dunia secara lebih bervariasi, lebih fleksibel dalam menghadapi masalah, dan mampu mengekspresikan dirinya dalam cara berbeda dari umumnya orang lain yang dapat muncul dari pengalaman yang dimilikinya.

6) Urutan kelahiran (berdasarkan tes kreativitas, anak sulung laki-laki lebih kreatif dari pada anak lakilaki yang lahir kemudian)

7) Perhatian dari orang tua terhadap minat anaknya, stimulasi dari lingkungan sekolah, dan motivasi diri.

Sedangkan faktor-faktor yang menghambat berkembang nya kreativitas alah sebagai berikut :

1) Adanya kebutuhan akan keberhasilan, ketidakberanian dalam menanggung resiko atau upaya mengejar sesuatu yang belum di ketahui.

2) Kompormitas terhadap temanteman kelompok dan tekanan sosial

3) Kurang berani dalam melakukan eksplorasi, menggunakan imajinasi, dan penyelidikan

4) Stereotif peran seks/jenis kelamin

5) Diferensiasi antara bekerja dan bermain

6) Otoritarianisme Tidak menghargai terhadap fantasi dan khayalan.

\section{Model Problem Solving}

Model Problem Solving (pemecahan masalah) adalah salah satu model pembelajaran yang digunakan oleh pendidik di kelas, pendidik memberikan suatu masalah dikelas kemudian peserta didik menjawab, menyatakan pendapat atau memberikan komentar sehingga mungkin masalah itu berkembang menjadi masalah yang baru. Model 
pemecahan masalah memberikan kesempatan peserta didik untuk berpikir secara kritis untuk memecahkan suatu permasalahan sehingga peserta didik dapat mengembangkan kemampuan berpikirnya.

Menurut Pepkin dalam Shoimin (2014, h. 135) menyatakan bahwa Model Problem Solving adalah suatu model pembelajaran yang melakukan pemusatan pada pengajaran dan keterampilan pemecahan masalah yang diikuti dengan penguatan keterampilan. Jadi, masalah dapat didefinisikan sebagai suatu persoalan yang tidak rutin dan belum dikenal cara penyelesaiannya. Problem Solving adalah mencari atau menemukan cara penyelesaian (menemukan pola atau aturan).

\section{Karakteristik Model Problem Solving}

Karakteristik penyelesaian masalah Problem Solving adalah menyelesaikan masalah secara bernalar dan ilmiah, maka dari itu untuk mendukung strategi belajar mengajar ini pendidik perlu memilih bahan pelajaran yang memiliki permasalahan. Materi pelajaran tidak sebatas hanya pada buku teks disekolah tetapi juga diambil dari sumber-sumber lingkungan seperti peristiwa kemasyarakatan. Mengenai model atau pendekatan pemecahan masalah (Problem Solving Approach), maka berikut ini karakteristik pemecahan masalah menurut Taplin dalam Permatasari (2012, h.151):

1) Terjadi interaksi antara peserta didik dengan peserta didik, dan interaksi pendidik dengan peserta didik.

2) Adanya dialog matematis dan konsesus antar peserta didik.
3) Pendidik menjelaskan latar belakang atau maksud dari masalah, dan peserta didik mengklarifikasi, menafsirkan, dan berusaha untuk membangun satu atau lebih proses solusi.

4) Pendidik menerima jawaban benar atau salah dalam cara non evaluative (tanpa mengevaluasi).

5) Pendidik membimbing melatih dan mengajukan pertanyaan dan berbagi wawasan dalam proses pemecahan masalah.

6) Pendidik mengetahui kapan saat yang tepat untuk campur tangan dan kapan harus melangkah mundur dan membiarkan peserta didik membuat jalan mereka sendiri.

\section{Prinsip Model Problem Solving}

Problem Solving merupakan representasi dimensi-dimensi proses yang alami, bukan suatu usaha yang dipaksakan. Problem Solving juga merupakan pendekatan yang dinamis, peserta didik mempunyai posedur internal yang lebih tersusun dari awal.Terdapat banyak kegiatan yang melibatkan kreatifitas dalam pemecahan masalah seperti riset dokumen, Pengamatan terhadap lingkungan sekitar, kegiatan yang berkaitan dengan ilmu pengetahuan, dan penulisan yang kreatif. Model Problem Solving, peserta didik dapat memilih dan mengembangkan ide dan pemikirannya. Berbeda dengan hafalan yang sedikit menggunakan pemikiran, Problem Solving memperluas proses berpikir.

Menurut Iskandar (2017, h.12) ada tiga prinsip yang ada pada Problem Solving, yaitu:

1) Problem Solving merupakan keterampilan yang biasa dipelajari dan bukan merupakan bakat yang 
hanya dimiliki oleh sebagian orang saja.

2) Problem Solving merupakan kerangka berpikir yang sistematis dan utuh untuk mendapatkan solusi.

3) Problem Solving merupakan kombinasi antara berpikir dan bertindak. Peneliti menyimpulkan bahwa prinsip Problem Solving merupakan keterampilan yang biasa dipelajari, kerangka berpikir yang sitematis, dan kombinasi antara berpikir dan bertindak.

\section{Langkah-langkah Model Problem Solving}

Model Problem Solving atau model pemecahan masalah bukan hanya sekedar metode mengajar. Model Problem Solving merupakan suatu metode berpikir sebab dalam Problem Solving dapat digunakan metode-metode lain yang dimulai dengan mencari data sampai pada menarik kesimpulan.

Langkah-langkah dalam penggunaan model Problem Solving menurut Shoimin (2014, h. 137) sebagai berikut:

1) Masalah sudah ada dan materi diberikan.

2) Peserta didik diberi masalah sebagai pemecahan/diskusi, kerja kelompok.

3) Masalah tidak dicari (sebagaimana pada problem based learning dari kehidupan mereka sehari-hari). Peserta didik ditugaskan mengevaluasi (evaluating) dan bukan grapping seperti pada problem based learning.

4) Peserta didik memberikan kesimpulan dari jawaban yang diberikan sebagai hasil akhir.

5) Penerapan pemecahan masalah terhadap masalah yang dihadapi sekaligus berlaku sebagai pengujian kebenaran pemecahan tersebut untuk dapat sampai kepada kesimpulan

\section{Kelebihan dan Kekurangan Model Problem Solving}

Setiap model pembelajaran tentunya memiliki kelebihan dan kekurangan, begitu pula dengan pembelajaran Problem Solving ini memiliki kelebihan dan kelemahan. Adapun kelebihan dan kelemahan pada model pembelajaran Problem Solving menurut Shoimin (2014: 137138), yaitu :

Kelebihan pada model Problem Solving

1) Dapat membuat peserta ddik lebih menghayati kehidupan seharihari.

2) Dapat membuat peserta ddik lebihmenghayati kehidupan sehari-hari.

3) Dapat melatih dan membiasakan para peserta didik untuk menghadapi dan memecahkan masalah secara terampil.

4) Dapat mengembangkan kemampuan berpikir peserta didik secara kreatif.

5) Peserta didik sudah mulai dilatih untuk memecahkan masalahnya.

6) Melatih peserta didik untuk mendesain suatu penemuan.

7) Berpikir dan bertindak kreatif.

8) Memecahkan masalah yang dihadapi secara realistis.

9) Mengidentifikasi dan melakukan penyelidikan.

10) Menafsirkan dan mengevaluasi hasil pengamatan.

Kelemahan pada model Problem Solving

1) Memerlukan cukup banyak waktu.

2) Melibatkan banyak orang. 
3) Dapat mengubah kebiasaan peserta didik belajar dengan mendengarkan dan menerima informasi dari pendidik.

4) Dapat diterapkan secara langsung yaitu untuk memecahkan masalah.

5) Beberapa pokok bahasan sangat sulit untuk menerapkan metode ini. Misalnya terbatasnya alat-alat laboratorium menyulitkan peserta didik untuk melihat dan mengamati serta akhirnya dapat menyimpulkan kejadian atau konsep tersebut.

6) Memerlukan alokasi waktu yang lebih panjang dibandingkan dengan metode pembelajaran yang lain.

\section{B. METODOLOGI PENELITIAN}

Metode penelitian yang digunakan dalam penelitian ini yaitu metode action research atau penelitian tindakan. Perencanaan penelitian tindakan ini menggunakan tiga siklus dengan perkiraan dalam tiga siklus target pembelajaran dapat dicapai. Karena fokus penelitian ini bertujuan untuk memperoleh gambaran di lapangan tentang sikap positif belajar dan kreativitas anak melalui bermain balok, maka penelitian ini adalah penelitian deskriptif kualitatif.

Penelitian ini dilaksanakan di Raudhatul Athfal (RA) Al Isro Bukit Cimanggu City, Tanah Sareal Kota Bogor pada kelompok B (anak usia 56 tahun) yang berjumlah 12 anak yang dilaksanakan pada akhir bulan Agustus dan selama bulan September
2019. Penjadwalan kegiatan penelitian disesuaikan dengan jadwal pembelajaran di semester 1 .

\section{HASIL DAN PEMBAHASAN Pra-siklus \\ Sebelum melaksanakan} intervensi tindakan, pada awal penelitian dilakukan wawancara dan asessmen pra siklus dengan tujuan untuk mengetahui kondisi awal sikap positif belajar siswa kelompok B RA Al Isro. Berdasarkan hasil pengamatan dan wawancara yang diperoleh, perbedaan sikap positif belajar tiaptiap anak disebabkan oleh berbagai faktor diantaranya kegiatan pembelajaran yang masih berpusat pada guru dan kurang menggali kreativitas anak dalam pembelajaran juga dikarenakan pola asuh orangtua. Bila ditinjau dari segi ekonomi keluarga rata-rata orang tua siswa RA Al Isro Bogor memiliki kemampuan yang cukup mapan, namun masalahnya ada pada perhatian orang tua. Bagi orangtuanya yang sibuk bekerja cenderung menyerahkan pengasuhan anak pada pembantu rumah tangga sehingga anak kurang mendapatkan perhatian dan stimulus dalam memecahkan masalah sederhana yang dijumpai dalam kehidupan sehari-hari. Sedangkan anak yang salah satu orangtuanya bekerja atau bekerja tapi tidak terlalu sibuk, biasanya mendapat perhatian lebih dari orang tua sehingga sikap positif belajar dan kreativitasnya berkembang cukup baik. 
Tabel 1 Hasil Observasi Sikap Positif Belajar Pra siklus

\begin{tabular}{|c|c|c|c|c|c|c|c|c|c|c|c|c|c|c|c|c|}
\hline \multicolumn{17}{|l|}{ Pra Siklus } \\
\hline & Adriano & Aira & Aisyah & Alexa & Bilal & \begin{tabular}{|l|} 
Fadhil \\
\end{tabular} & \begin{tabular}{|l|} 
Farraas \\
\end{tabular} & \begin{tabular}{|l|} 
Fawas \\
\end{tabular} & Kayla & Laras & Radin & Zkki & SKOR & MAX & $\%$ & Kriteria \\
\hline Antusias & 33,33 & 33,33 & 25,00 & 25,00 & 33,33 & 33,33 & 41,67 & 25,00 & 25,00 & 41,67 & 25,00 & 50,00 & 391,6667 & 1200 & 32,64 & MB \\
\hline Rasa Ingin tahu & 50,00 & 33,33 & 41,67 & 58,33 & 50,00 & 58,33 & 50,00 & 58,33 & 50,00 & 50,00 & 50,00 & 75,00 & 625,00 & 1200 & 52,08 & BSH \\
\hline Berkonsentrasi & 25,00 & 25,00 & 25,00 & 33,33 & 41,67 & 33,33 & 25,00 & 33,33 & 33,33 & 25,00 & 25,00 & 33,33 & 358,3333 & 1200 & 29,86 & MB \\
\hline Cermat & 33,33 & 41,67 & 41,67 & 33,33 & 41,67 & 33,33 & 33,33 & 33,33 & 33,33 & 33,33 & 33,33 & 25,00 & 416,6667 & 1200 & 34,72 & MB \\
\hline Menggunakan alat bantu (balok) dengan cepat & 50,00 & 37,50 & 37,50 & 37,50 & 37,50 & 37,50 & 37,50 & 37,50 & 37,50 & 50,00 & 37,50 & 37,50 & 475 & 1200 & 39,58 & MB \\
\hline Bersungguh-sungguh & 50,00 & 50,00 & 50,00 & 62,50 & 50,00 & 37,50 & 37,50 & 37,50 & 37,50 & 37,50 & 37,50 & 50,00 & 537,5 & 1200 & 44,79 & MB \\
\hline Fokus & 50,00 & 50,00 & 50,00 & 50,00 & 50,00 & 37,50 & 31,25 & 31,25 & 25,00 & 43,75 & 50,00 & 50,00 & 518,75 & 1200 & 43,23 & MB \\
\hline SKOR & 291,67 & 270,83 & 270,83 & 300,00 & 304,17 & 270,83 & 256,25 & 256,25 & 241,67 & 281,25 & 258,33 & 320,83 & & & & \\
\hline MAX & 700 & 700 & 700 & 700 & 700 & 700 & 700 & 700 & 700 & 700 & 700 & 700 & & & & \\
\hline$\%$ & 41,67 & 38,69 & 38,69 & 42,86 & 43,45 & 38,69 & 36,61 & 36,61 & 34,52 & 40,18 & 36,90 & 45,83 & & $\%$ & $\%$ & 39,56 \\
\hline Kniteria & MB & MB & MB & MB & MB & MB & MB & MB & MB & MB & MB & MB & & & Kriteria & MB \\
\hline
\end{tabular}

Data tersebut di atas, jika dalam bentuk grafik akan nampak pada grafik1 berikut.

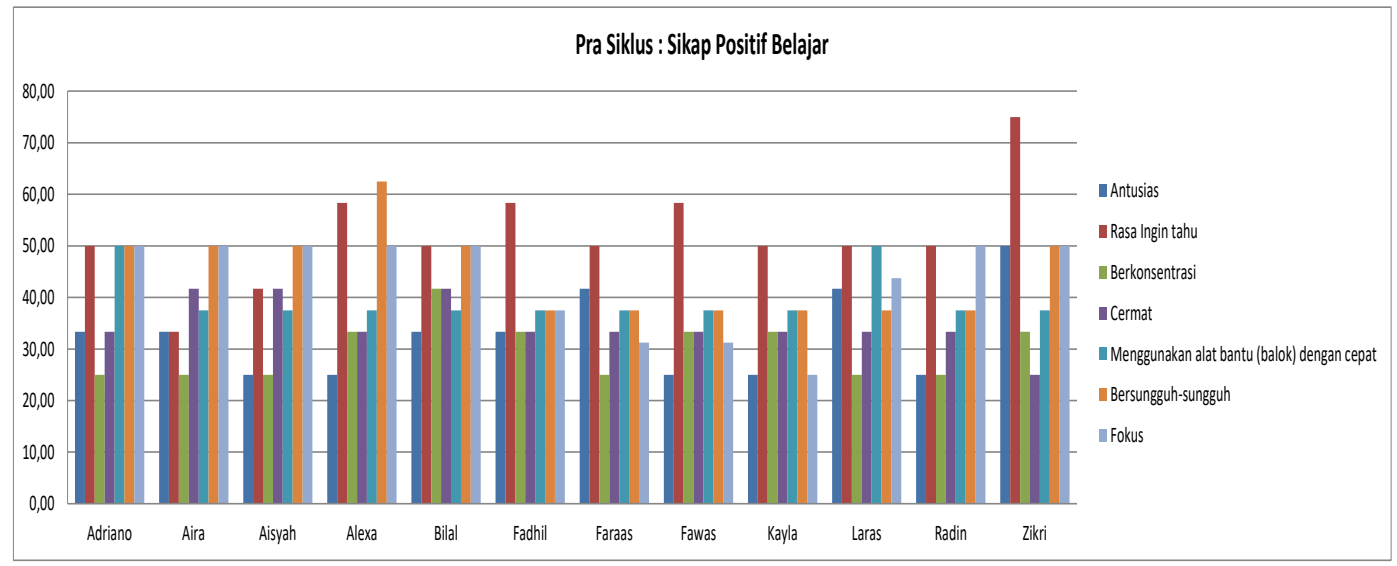

Grafik 1. Sikap Positif Belajar Pra Siklus

Apabila digambarkan dalam bentuk diagram, capaian perkembangan kemampuan memecahkan masalah pra siklus sebagai berikut :

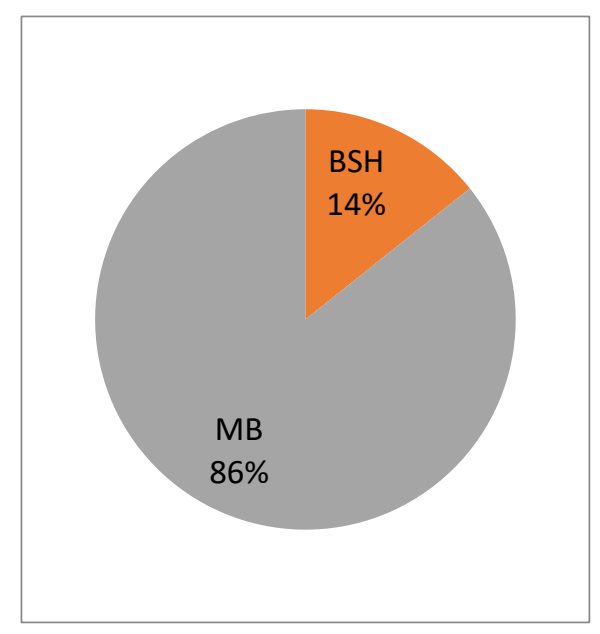

Diagram 1. Prosentase Rata-rata Kemampuan Memecahkan Masalah Pra siklus

Dari diagram 1 di atas, dapat diamati bahwa anak yang mendapakan nilai 26-50 ( Mulai Berkembang) memiliki prosentase 86\% sebanyak 10 anak yaitu Adriano, Aira, Aisyah, Bilal, Fadhil, Faraas, Fawas, Kayla, Laras dan Radin. Yang mendapatkan nilai 51-75 (Berkembang Sesuai Harapan) memiliki prosentase $14 \%$ sebanyak 2 anak, yaitu alexa dan Zikri. Sedangkan untuk anak dengan kriteria nilai 76-100 (Berkembang Sangat Baik) belum ada. Hal ini menunjukkan bahwa sebagian besar 
sikap positif belajar anak Kelompok B RA Al Isro Bogor masih rendah, dengan demikian sikap positif belajar anak TK B kelompok B RA Al Isro perlu ditingkatkan.
Dilihat dari hasil observasi pra siklus diperoleh hasil observasi kreativitas sebagaimana yang terlihat pada tabel di bawah ini:

Tabel 2 Hasil Observasi Kreativitas Pra Siklus

\begin{tabular}{|c|c|c|c|c|c|c|c|c|c|c|c|c|c|}
\hline \multicolumn{14}{|c|}{ PRA SIKLUS } \\
\hline & Instrumen Kreativitas Anak & \multicolumn{12}{|c|}{ Nama Anak } \\
\hline & Aspek yang di nilai & Adriand & Aira & Aisyah & Alexa & Bilal & Fadhil & Faraas & Fawas & Kayla & Laras & Radin & Zikri \\
\hline 1 & $\begin{array}{l}\text { Anak mempunyai inisiatif } \\
\text { dalam mengikuti pembelajaran }\end{array}$ & 1 & 1 & 1 & 1 & 1 & 1 & 1 & 1 & 1 & 1 & 1 & 1 \\
\hline 2 & $\begin{array}{l}\text { Anak idealis dalam } \\
\text { pembelajaran }\end{array}$ & 1 & 1 & 1 & 1 & 1 & 1 & 1 & 1 & 1 & 1 & 1 & 1 \\
\hline 3 & $\begin{array}{l}\text { Anak berwawasan ke depan } \\
\text { (visioner) }\end{array}$ & 1 & 1 & 1 & 1 & 1 & 1 & 1 & 1 & 1 & 1 & 1 & 1 \\
\hline 4 & $\begin{array}{l}\text { Anak menunjukkan sikap } \\
\text { banyak akal }\end{array}$ & 1 & 1 & 1 & 1 & 1 & 1 & 1 & 1 & 1 & 1 & 1 & 1 \\
\hline 5 & Anak berfikiran terbuka & 1 & 1 & 1 & 1 & 1 & 1 & 1 & 1 & 1 & 1 & 1 & 1 \\
\hline 6 & Anak berfikiran kritis & 1 & 1 & 1 & 1 & 1 & 1 & 1 & 1 & 1 & 1 & 1 & 1 \\
\hline 7 & $\begin{array}{l}\text { Anak antusias dalam } \\
\text { pembelajaran }\end{array}$ & 1 & 1 & 1 & 1 & 1 & 2 & 1 & 1 & 1 & 2 & 1 & 1 \\
\hline 8 & Anak memiliki rasa ingin tahu & 1 & 1 & 1 & 1 & 1 & 1 & 1 & 1 & 1 & 1 & 1 & 1 \\
\hline 9 & Anak memiliki sikap ulet & 1 & 1 & 1 & 1 & 1 & 1 & 1 & 1 & 1 & 1 & 1 & 1 \\
\hline 10 & Anak berperilaku spontan & 1 & 1 & 1 & 1 & 1 & 1 & 1 & 1 & 1 & 1 & 1 & 1 \\
\hline 11 & Anak peka & 1 & 1 & 1 & 1 & 1 & 1 & 1 & 1 & 1 & 1 & 1 & 1 \\
\hline 12 & Anak percaya diri & 1 & 1 & 1 & 1 & 1 & 1 & 1 & 1 & 1 & 1 & 1 & 1 \\
\hline & Skor & 12 & 12 & 12 & 12 & 12 & 13 & 12 & 12 & 12 & 13 & 12 & 12 \\
\hline & Max & 48 & 48 & 48 & 48 & 48 & 48 & 48 & 48 & 48 & 48 & 48 & 48 \\
\hline & $\%$ & 25,00 & 25,00 & 25,00 & 25,00 & 25,00 & 27,08 & 25,00 & 25,00 & 25,00 & 27,08 & 25,00 & 25,00 \\
\hline & Kriteria & Kurang & Kurang & Kurang & Kurang & Kurang & Cukup & Kurang & Kurang & Kurang & Cukup & Kurang & Kurang \\
\hline
\end{tabular}

Apabila digambarkan dalam bentuk grafik, hasil observasi kreatifitas anak pra siklus sebagai berikut :

Pra-Siklus : Kreativitas Anak

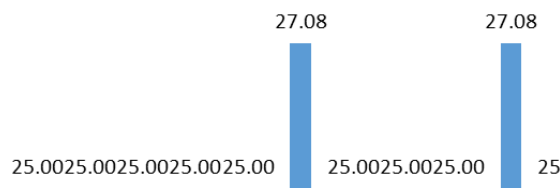

27.08

25.0025 .00
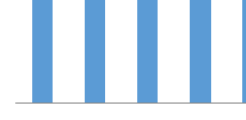

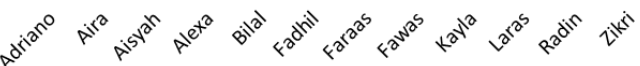

Grafik 2. Observasi Kreativitas Anak Pra Siklus

Dari grafik di atas terlihat kreativitas anak dalam kegiatan pembelajaran memecahkan masalah masih pada kategori cukup yaitu $17 \%$, selebihnya ada pada kategori kurang sebesar $73 \%$, oleh karena itu harus dirancang kegiatan pembelajaran yang dapat meningkatkan kreativitas anak, sehingga kreativitas anak ketika pembelajaran memecahkan kemampuan memecahkan masalah menjadi tinggi atau bahkan sangat tinggi.

Berdasarkan uraian di atas, maka peneliti mencoba meningkatkan kreativitas Kelompok B melalui model pembelajaran problem solving dengan merancang kegiatan pembelajaran yang memungkinkan tercapainya peningkatan kreativitas anak sehingga hipotesis penelitian ini adalah kreativitas anak TK kelompok B diduga akan meningkat setelah diterapkan model pembelajaran Problem Solving yang akan dilaksanakan selama satu siklus yang terdiri dari 2 kali pertemuan. Apabila selama 2 kali pertemuan belum ada peningkatan yang signifikan maka akan diadakan intervensi tindakan siklus dua, dan seterusnya. 
Siklus I

Berdasarkan hasil observasi, peningkatan kemampuan memecahkan masalah anak melalui model pembelajaran problem solving dengan menggunakan media balok pada siklus I terlihat pada tabel berikut:

Tabel 3 Nilai Hasil Observasi Kemampuan Memecahkan Masalah Siklus I

Siklus I

\begin{tabular}{|l|c|c|c|c|c|c|c|c|c|c|c|c|}
\cline { 2 - 14 } \multicolumn{1}{c|}{} & Adriano & Aira & Aisyah & Alexa & Bilal & Fadhil & Faras & Fawas & Kayla & Laras & Radin & Zikri \\
\hline Antusias & 41.67 & 66.67 & 58.33 & 58.33 & 58.33 & 50 & 58.33 & 50 & 66.67 & 66.67 & 66.67 & 50 \\
\hline Rasa Ingin tahu & 50 & 50 & 50 & 50 & 58.33 & 50 & 50 & 50 & 50 & 41.67 & 41.67 & 41.67 \\
\hline Berkonsentrasi & 41.67 & 41.67 & 41.67 & 41.67 & 41.67 & 41.67 & 41.67 & 41.67 & 41.67 & 41.67 & 41.67 & 25 \\
\hline Cermat & 50 & 50 & 50 & 50 & 58.33 & 50 & 50 & 50 & 50 & 50 & 58.33 & 58.33 \\
\hline $\begin{array}{l}\text { Menggunakan alat bantu } \\
\text { (balok) dengan cepat }\end{array}$ & 50 & 50 & 50 & 50 & 62.5 & 50 & 50 & 50 & 50 & 50 & 62.5 & 62.5 \\
\hline Bersungguh-sungguh & 50 & 50 & 50 & 62.5 & 62.5 & 50 & 50 & 50 & 50 & 50 & 62.5 & 62.5 \\
\hline Fokus & 50 & 50 & 50 & 50 & 68.75 & 43.75 & 37.5 & 37.5 & 31.25 & 50 & 68.75 & 68.75 \\
\hline \multicolumn{1}{|c|}{ SKOR } & 333.33 & 358.33 & 350 & 362.5 & 410.4 & 335.4 & 337.5 & 329.2 & 339.6 & 350 & 402.08 & 368.75 \\
\hline \multicolumn{1}{|c|}{ MAX } & 700 & 700 & 700 & 700 & 700 & 700 & 700 & 700 & 700 & 700 & 700 & 700 \\
\hline \multicolumn{1}{|c|}{$\%$} & 47.62 & 51.19 & 50 & 51.79 & 58.63 & 47.92 & 48.21 & 47.02 & 48.51 & 50 & 57.44 & 52.68 \\
\hline Kriteria & MB & BSH & MB & BSH & BSH & MB & MB & MB & MB & MB & BSH & BSH \\
\hline
\end{tabular}

Data tersebut di atas bila dalam bentuk diagram akan terlihat pada grafik di bawah ini :

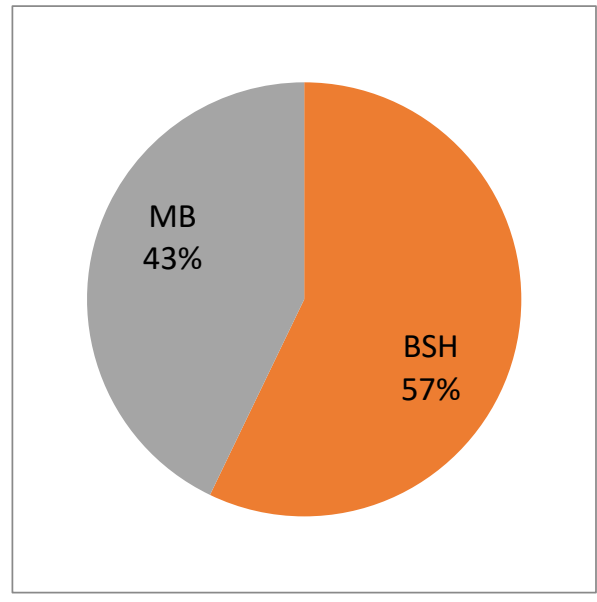

Diagram 2 Prosentase Rata-rata Kemampuan Memecahkan Masalah Siklus I

Dari Gambar grafik di atas dapat diamati bahwa kemampuan memecahkan masalah mengalami peningkatan dari rata-rata kelas $46 \%$ menjadi $61 \%$ dimana dapat dilihat dari anak yang mendapatkan nilai 0 25 (Belum Berkembang) yang tadinya memiliki prosentase $9 \%$ menjadi $0 \%$. Sedangkan yang mendapakan nilai 26-50 ( Mulai Berkembang) yang tadinya memiliki prosentase $61 \%$ menjadi $31 \%$, yang mendapatkan nilai 51-75 (Berkembang Sesuai Harapan) naik dari $30 \%$ saat abservasi pra siklus menjadi $54 \%$ dan untuk anak dengan kriteria nilai 76-100 (Berkembang Sangat Baik) yang tadinya $0 \%$ meningkat menjadi $15 \%$. Nilai anak mulai bergeser yang tadinya belum berkembang sudah mulai menuju mulai berkembang, dan yang awalnya mulai berkembang menuju berkembang sesuai harapan.

Kreativitas anak selama proses intervensi tindakan pembelajaran memecahkan masalah melalui model pembelajaran problem solving dapat terlihat pada tabel dibawah ini: 
Tabel 4 Hasil Observasi Kreativitas Anak Siklus I

\begin{tabular}{|c|c|c|c|c|c|c|c|c|c|c|c|c|c|}
\hline \multicolumn{14}{|c|}{ SIKLUS I } \\
\hline & Instrumen Kreativitas & \multicolumn{12}{|c|}{ Nama Anak } \\
\hline & Aspek yang di nilai & Adriano & Aira & Aisyah & Alexa & Bilal & Fadhil & Faraas & Fawas & Kayla & Laras & Radin & Zikri \\
\hline 1 & \begin{tabular}{|l|} 
Anak mempunyai \\
inisiatif dalam \\
mengikuti \\
pembelajaran \\
\end{tabular} & 2 & 1 & 2 & 2 & 2 & 2 & 1 & 2 & 1 & 3 & 2 & 2 \\
\hline 2 & $\begin{array}{l}\text { Anak idealis dalam } \\
\text { pembelajaran }\end{array}$ & 1 & 1 & 1 & 1 & 1 & 2 & 1 & 1 & 1 & 2 & 1 & 1 \\
\hline 3 & $\begin{array}{l}\text { Anak berwawasan ke } \\
\text { depan (visioner) }\end{array}$ & 1 & 1 & 1 & 1 & 1 & 2 & 1 & 1 & 1 & 2 & 1 & 1 \\
\hline 4 & $\begin{array}{l}\text { Anak menunjukkan } \\
\text { sikap banyak akal }\end{array}$ & 2 & 2 & 1 & 1 & 1 & 2 & 1 & 1 & 1 & 2 & 1 & 1 \\
\hline 5 & $\begin{array}{l}\text { Anak berfikiran } \\
\text { terbuka }\end{array}$ & 1 & 1 & 2 & 1 & 2 & 2 & 1 & 1 & 1 & 2 & 2 & 2 \\
\hline 6 & Anak berfikiran kritis & 1 & 1 & 1 & 1 & 1 & 2 & 1 & 1 & 1 & 2 & 1 & 1 \\
\hline 7 & $\begin{array}{l}\text { Anak antusias dalam } \\
\text { pembelajaran }\end{array}$ & 2 & 2 & 2 & 2 & 3 & 3 & 1 & 2 & 2 & 2 & 3 & 3 \\
\hline 8 & $\begin{array}{l}\text { Anak memiliki rasa } \\
\text { ingin tahu }\end{array}$ & 1 & 2 & 1 & 1 & 1 & 2 & 1 & 1 & 2 & 2 & 1 & 1 \\
\hline 9 & $\begin{array}{l}\text { Anak memiliki sikap } \\
\text { ulet }\end{array}$ & 1 & 1 & 2 & 1 & 2 & 2 & 1 & 1 & 1 & 2 & 2 & 2 \\
\hline 10 & $\begin{array}{l}\text { Anak berperilaku } \\
\text { spontan }\end{array}$ & 1 & 1 & 1 & 1 & 1 & 2 & 1 & 1 & 1 & 2 & 1 & 1 \\
\hline 11 & Anak peka & 2 & 1 & 2 & 2 & 2 & 2 & 1 & 2 & 1 & 2 & 2 & 2 \\
\hline 12 & Anak percaya diri & 1 & 1 & 1 & 1 & 1 & 2 & 1 & 1 & 1 & 2 & 1 & 1 \\
\hline & Skor & 16 & 15 & 17 & 15 & 18 & 25 & 12 & 15 & 14 & 25 & 18 & 18 \\
\hline & Max & 48 & 48 & 48 & 48 & 48 & 48 & 48 & 48 & 48 & 48 & 48 & 48 \\
\hline & $\%$ & 33.33 & 31.25 & 35.42 & 31.25 & 37.5 & 52.08 & 25 & 31.25 & 29.17 & 52.08 & 37.5 & 37.5 \\
\hline & Kriteria & Cukup & Cukup & Cukup & Cukup & Cukup & Tinggi & Kurang & Cukup & Cukup & Tinggi & Cukup & Cukup \\
\hline
\end{tabular}

Data kreativitas anak pada tabel di atas jika digambarkan dalam grafik sebagai berikut:

Siklus I : Kreativitas Anak

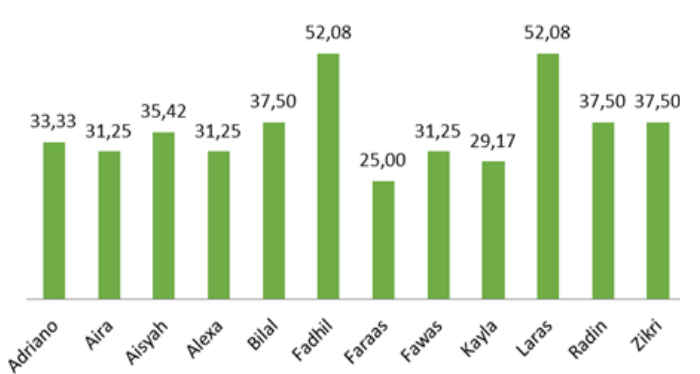

Grafik 3 Hasil Observasi Kreativitas Anak Siklus I

Di lihat dari hasil grafik di atas terlihat perubahan kreativitas anak bila dibandingkan dengan sebelum dilakukannya pembelajaran model problem solving dengan menggunakan media balok, terlihat prosentase nilai observasi kreativitas anak saat pra siklus sebesar $44 \%$ (kategori Cukup) meningkat ketika diberlakukan pembelajaran problem solving pada siklus I menjadi $67 \%$ (kategori Tinggi), begitu pula dengan kreativitas setiap anak rata-rata sudah mengalami peningkatan walaupun belum sampai pada hasil yang diharapkan. Jadi kreativitas anak ini masih memungkinkan untuk ditingkatkan lagi.

\section{Siklus II}

Pelaksanaan tindakan pada Siklus 2 ini dilakukan sebanyak 2 kali pertemuan, yaitu pada tanggal 9 dan 11 Agustus 2019. Perencanaan yang dilakukan pada Siklus II ini sebenarnya hampir sama dengan perencanaan pada Siklus I. 
Tabel 5 Hasil Observasi Kemampuan Memecahkan Masalah Siklus II

\begin{tabular}{|c|c|c|c|c|c|c|c|c|c|c|c|c|}
\hline \multicolumn{13}{|l|}{ Siklus II } \\
\hline & Adriano & Aira & Aisyah & Alexa & Bilal & Fadhil & Faraas & Fawas & Kayla & Laras & Radin & Zikri \\
\hline Antusias & 58.33 & 66.67 & 58.33 & 58.33 & 58.33 & 66.67 & 58.33 & 58.33 & 66.67 & 66.67 & 66.67 & 66.67 \\
\hline Rasa Ingin tahu & 58.33 & 58.33 & 58.33 & 58.33 & 66.67 & 58.33 & \begin{tabular}{|c|}
58.33 \\
\end{tabular} & \begin{tabular}{|l|l|}
58.33 \\
\end{tabular} & 58.33 & 50 & 66.67 & \begin{tabular}{|c|}
66.67 \\
\end{tabular} \\
\hline Berkonsentrasi & 58.33 & 58.33 & 58.33 & 58.33 & 75 & 58.33 & 58.33 & 58.33 & 58.33 & 58.33 & 66.67 & 66.67 \\
\hline Cermat & 58.33 & 58.33 & 58.33 & 58.33 & 66.67 & 58.33 & 58.33 & 58.33 & 58.33 & 58.33 & 75 & 66.67 \\
\hline $\begin{array}{l}\text { Menggunakan alat } \\
\text { bantu (balok) dengan } \\
\text { cepat }\end{array}$ & 62.5 & 62.5 & 62.5 & 62.5 & 75 & 62.5 & 62.5 & 62.5 & 62.5 & 62.5 & 75 & 75 \\
\hline Bersungguh-sungguh & 62.5 & 62.5 & 62.5 & 62.5 & 75 & 62.5 & 62.5 & 62.5 & 62.5 & 62.5 & 75 & 75 \\
\hline Fokus & 56.25 & 62.5 & 68.75 & 56.25 & 75 & 68.75 & 75 & 56.25 & 62.5 & 56.25 & 68.75 & 68.75 \\
\hline SKOR & 414.58 & 429.17 & 427.08 & 414.58 & 491.67 & 435.42 & 433.33 & 414.58 & 429.17 & 414.58 & 493.75 & 485.42 \\
\hline MAX & 700 & 700 & 700 & 700 & 700 & 700 & 700 & 700 & 700 & 700 & 700 & 700 \\
\hline$\%$ & 59.23 & 61.31 & 61.01 & 59.23 & 70.24 & 62.2 & 61.9 & 59.23 & 61.31 & 59.23 & 70.54 & 69.35 \\
\hline Kriteria & BSH & BSH & BSH & BSH & BSH & BSH & BSH & BSH & BSH & BSH & BSH & BSH \\
\hline
\end{tabular}

Apabila digambarkan dalam bentuk grafik, hasil observasi kemampuan memecahkan masalah siklus 2 sebagai berikut :

Siklus II: KemampuanMemecahkan Masalah

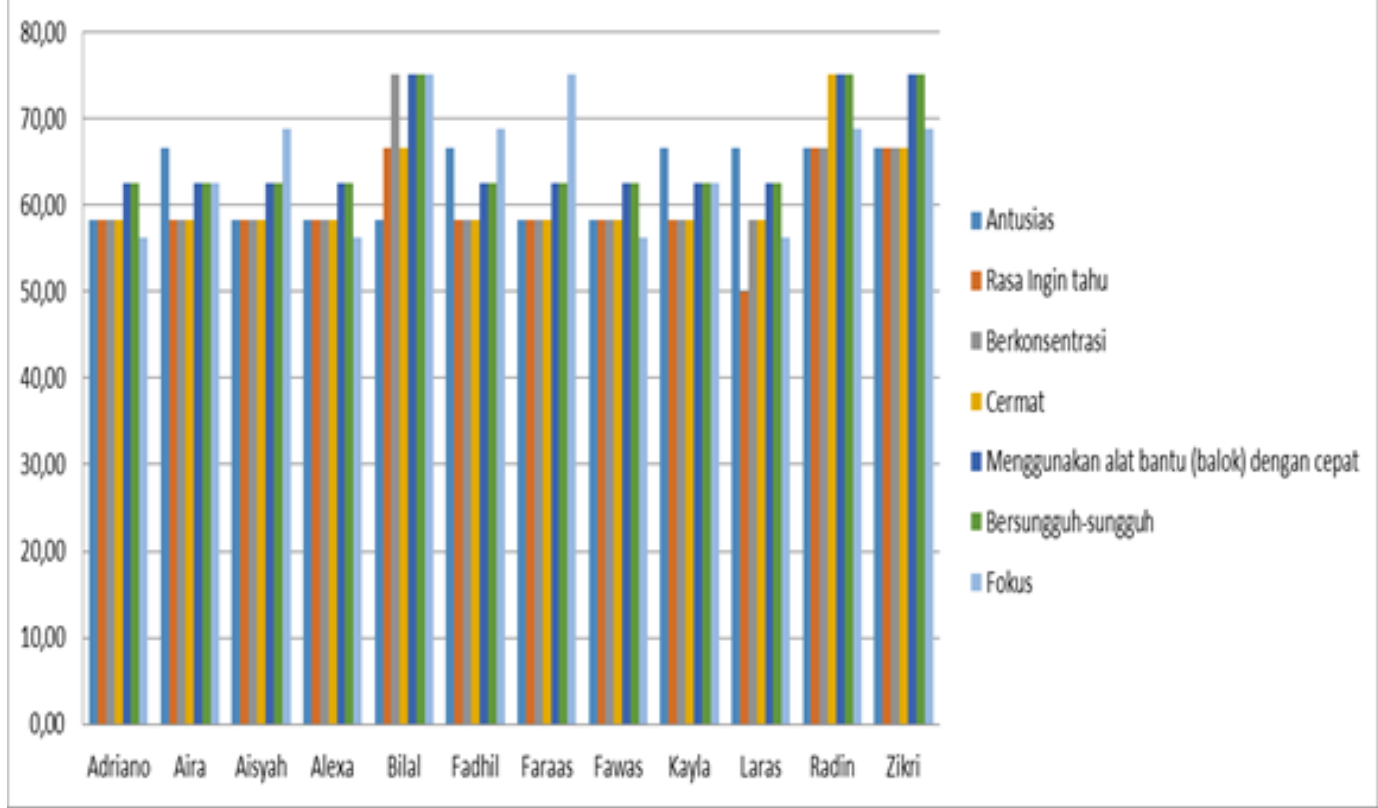

Grafik 4 Hasil Observasi Kemampuan Memecahkan Masalah Siklus II

Dari Gambar grafik di atas dapat diamati bahwa kemampuan memecahkan masalah mengalami peningkatan dari rata-rata kelas $50.92 \%$ pada tindakan siklus I menjadi $62,90 \%$ pada siklus II ini. Untuk yang mendapakan nilai 26-50 ( Mulai Berkembang) sudah tidak ada pada siklus 2, yang mendapatkan nilai
51-75 (Berkembang Sesuai Harapan) ada pada prosentase $100 \%$ dan untuk anak dengan kriteria nilai 76-100 (Berkembang Sangat Baik) belum ada.

Pada siklus II ini dalam hal kreativitas, anak pun mengalami peningkatan, terlihat pada perolehan nilai pada tabel di bawah ini: 
Tabel 6 Hasil Observasi Kreativitas Siklus II

\begin{tabular}{|c|c|c|c|c|c|c|c|c|c|c|c|c|}
\hline \multicolumn{13}{|c|}{ SIKLUS II KREATIVITAS ANAK } \\
\hline \multirow{2}{*}{\begin{tabular}{|l}
$\begin{array}{l}\text { Instrumen Kreativitas } \\
\text { Anak }\end{array}$ \\
Aspek yang di nilai \\
\end{tabular}} & \multicolumn{12}{|c|}{ Nama Anak } \\
\hline & Adriano & Aira & Aisyah & Alexa & Bilal & Fadhil & Faraas & Fawas & Kayla & Laras & Radin & Zikri \\
\hline \begin{tabular}{|l|} 
Anak mempunyai \\
inisiatif dalam \\
mengikuti \\
pembelajaran \\
\end{tabular} & 3 & 3 & 3 & 3 & 3 & 4 & 3 & 3 & 3 & 4 & 3 & 3 \\
\hline $\begin{array}{l}\text { Anak idealis dalam } \\
\text { pembelajaran }\end{array}$ & 2 & 2 & 2 & 2 & 2 & 3 & 2 & 2 & 2 & 3 & 2 & 3 \\
\hline $\begin{array}{l}\text { Anak berwawasan ke } \\
\text { depan (visioner) }\end{array}$ & 2 & 2 & 2 & 2 & 2 & 3 & 2 & 2 & 2 & 3 & 2 & 3 \\
\hline $\begin{array}{l}\text { Anak menunjukkan } \\
\text { sikap banyak akal }\end{array}$ & 3 & 3 & 3 & 3 & 3 & 4 & 3 & 3 & 3 & 3 & 3 & 3 \\
\hline $\begin{array}{l}\text { Anak berfikiran } \\
\text { terbuka }\end{array}$ & 2 & 2 & 2 & 2 & 2 & 4 & 2 & 2 & 2 & 4 & 3 & 3 \\
\hline Anak berfikiran kritis & 2 & 2 & 2 & 2 & 2 & 3 & 2 & 2 & 2 & 2 & 3 & 3 \\
\hline $\begin{array}{l}\text { Anak antusias dalam } \\
\text { pembelajaran }\end{array}$ & 3 & 3 & 3 & 3 & 3 & 4 & 3 & 3 & 3 & 3 & 3 & 3 \\
\hline $\begin{array}{l}\text { Anak memiliki rasa } \\
\text { ingin tahu }\end{array}$ & 3 & 3 & 3 & 3 & 4 & 3 & 3 & 3 & 3 & 3 & 3 & 3 \\
\hline $\begin{array}{l}\text { Anak memiliki sikap } \\
\text { ulet }\end{array}$ & 3 & 3 & 3 & 3 & 3 & 4 & 3 & 3 & 3 & 4 & 3 & 4 \\
\hline $\begin{array}{l}\text { Anak berperilaku } \\
\text { spontan }\end{array}$ & 3 & 3 & 3 & 3 & 3 & 4 & 3 & 3 & 4 & 3 & 3 & 4 \\
\hline Anak peka & 3 & 2 & 3 & 2 & 2 & 3 & 2 & 2 & 2 & 3 & 3 & 3 \\
\hline Anak percaya diri & 3 & 3 & 3 & 3 & 3 & 4 & 3 & 3 & 3 & 4 & 3 & 3 \\
\hline Skor & 32 & 31 & 32 & 31 & 32 & 43 & 31 & 31 & 32 & 39 & 34 & 38 \\
\hline Max & 48 & 48 & 48 & 48 & 48 & 48 & 48 & 48 & 48 & 48 & 48 & 48 \\
\hline$\%$ & 66,67 & 64,58 & 66,67 & 64,58 & 66,67 & 89,58 & 64,58 & 64,58 & 66,67 & 81,25 & 70,83 & 79,17 \\
\hline Kriteria & Tinggi & Tinggi & Tinggi & Tinggi & Tinggi & Tinggi & Tinggi & Tinggi & Tinggi & Tinggi & Tinggi & Tinggi \\
\hline
\end{tabular}

Untuk lebih jelasnya dapat terlihat pada grafik di bawah ini:

Siklus II : Kreativitas Anak

89,58

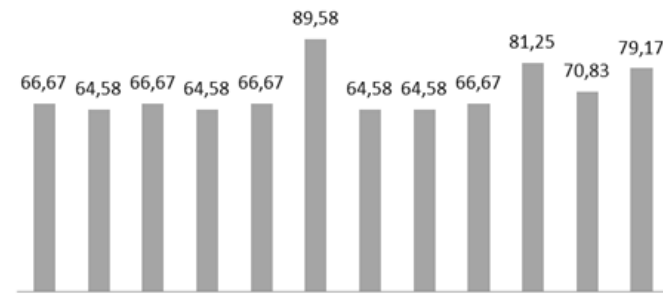

$0^{20}$

\section{Grafik 5 Hasil Observasi}

Kreativitas Siklus II

Di lihat dari hasil grafik di atas terlihat peningkatan kreatifitas belajar anak bila dibandingkan dengan tindakan pada siklus 1. Terlihat anak semakin kreatif ketika mereka mengkonstruksi kandang secara mandiri, hal ini bisa terlihat dari nilai observasi kreatif anak yang pada saat siklus 1 sebesar $36,11 \%$ (kategori Tinggi) meningkat menjadi $70,49 \%$. (Kategori Tinggi).

\section{Siklus III}

Pelaksanaan tindakan pada Siklus 3 ini dilakukan sebanyak 2 kali pertemuan, yaitu pada tanggal 16 dan 18 September 2019. Perencanaan yang dilakukan pada Siklus III ini sebenarnya hampir sama dengan perencanaan pada Siklus I dan II.

Perencanaan pada Siklus ke III ini pun dimulai dengan berkoordinasi dengan guru kelas untuk mendiskusikan berbagai refleksi yang dilakukan sebelumnya agar dapat diimplementasikan pada Siklus III. 
Tabel 7 Hasil Observasi Kemampuan Memecahkan Masalah Siklus III

Siklus III

\begin{tabular}{|c|c|c|c|c|c|c|c|c|c|c|c|c|}
\hline & Adriano & Aira & Aisyah & Alexa & Bilal & Fadhil & Faraas & Fawas & Kayla & Laras & Radin & Zikri \\
\hline Antusias & 83.33 & 83.33 & 91.67 & 83.33 & 100 & 83.33 & 83.33 & 100 & 83.33 & 100 & 100 & 100 \\
\hline Rasa Ingin tahu & 83.33 & 83.33 & 91.67 & 83.33 & 100 & 83.33 & 83.33 & 83.33 & 83.33 & 100 & 100 & 100 \\
\hline Berkonsentrasi & 83.33 & 83.33 & 83.33 & 83.33 & 100 & 83.33 & 83.33 & 91.67 & 75 & 100 & 100 & 100 \\
\hline Cermat & 3.33 & 75 & 83.33 & 83.33 & 91.67 & 83.33 & 83.33 & 75 & 75 & 100 & 100 & 100 \\
\hline $\begin{array}{l}\text { Menggunakan alat } \\
\text { bantu (balok) dengan } \\
\text { cepat }\end{array}$ & 87.5 & 87.5 & 87.5 & 87.5 & 100 & 87.5 & 87.5 & 87.5 & 87.5 & 100 & 100 & 100 \\
\hline Bersungguh-sungguh & 87.5 & 87.5 & 87.5 & 87.5 & 100 & 87.5 & 87.5 & 87.5 & 87.5 & 100 & 100 & 100 \\
\hline Fokus & 81.25 & 87.5 & 87.5 & 87.5 & 100 & 87.5 & 87.5 & 87.5 & 87.5 & 100 & 100 & 100 \\
\hline SKOR & 589.58 & 587.5 & 612.5 & 595.83 & 691.67 & 595.83 & 595.83 & 612.5 & 579.17 & 700 & 700 & 700 \\
\hline MAX & 700 & 700 & 700 & 700 & 700 & 700 & 700 & 700 & 700 & 700 & 700 & 700 \\
\hline$\%$ & 84.23 & 83.93 & 87.5 & 85.12 & 98.81 & 85.12 & 85.12 & 87.5 & 82.74 & 100 & 100 & 100 \\
\hline Kriteria & BSB & BSB & BSB & BSB & BSB & BSB & BSB & BSB & BSB & BSB & BSB & BSB \\
\hline
\end{tabular}

Berdasarkan data hasil observasi kemampuan memecahkan masalah Siklus III ini dapat diperjelas melalui grafik pada di bawah ini :

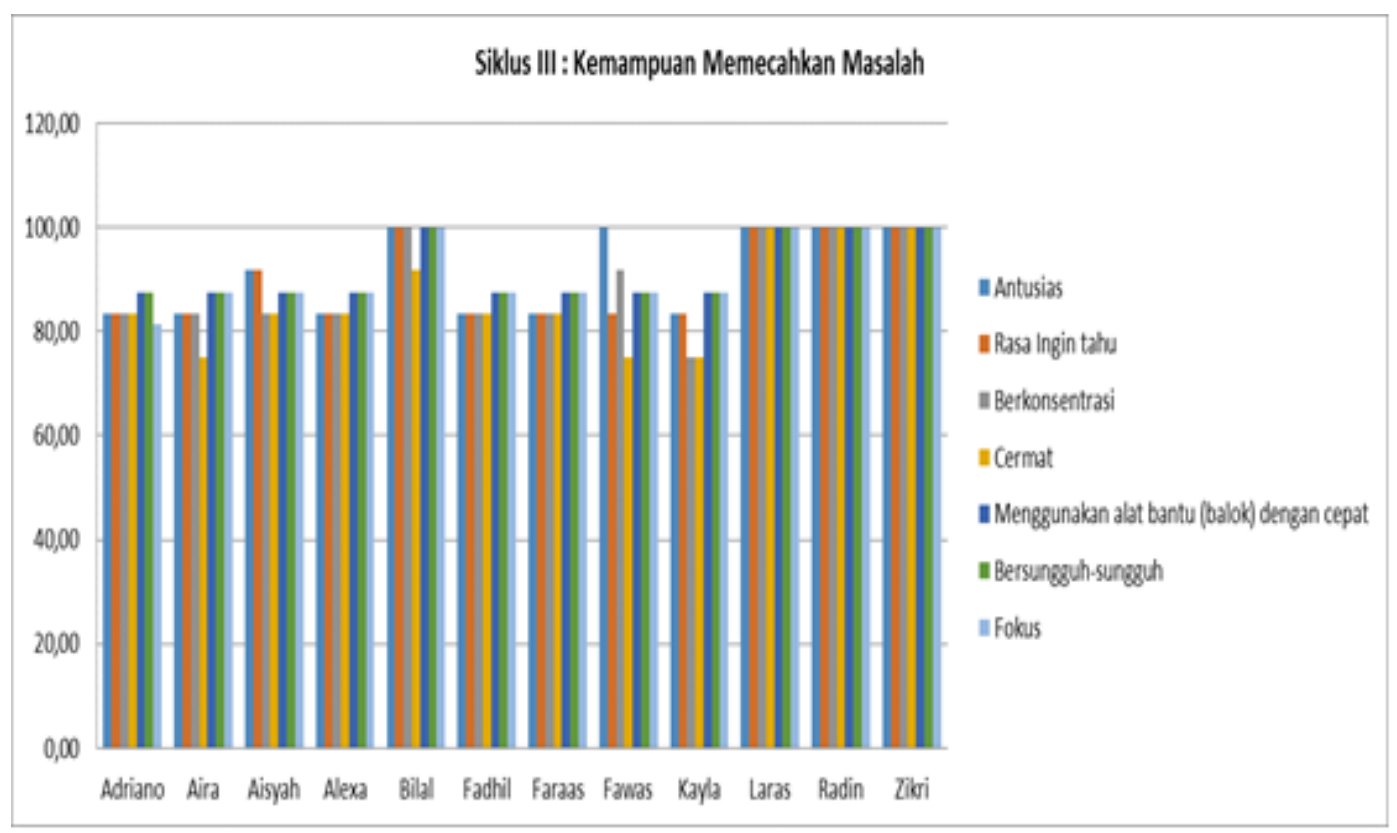

Grafik 6 Observasi Kemampuan Memecahkan Masalah Siklus III

Pada siklus ke III ini dalam hal kreativitas, anak pun mengalami peningkatan yang sangat baik, terlihat pada tabel data di bawah ini: 
Tabel 8 Hasil Observasi Kreativitas Anak Siklus III

\begin{tabular}{|c|c|c|c|c|c|c|c|c|c|c|c|c|}
\hline \multirow{2}{*}{$\begin{array}{l}\text { Instrumen Kreativitas } \\
\text { Anak } \\
\text { Aspek yang di nilai } \\
\end{array}$} & \multicolumn{12}{|c|}{ Nama Anak } \\
\hline & Adriano & Aira & Aisyah & Alexa & Bilal & Fadhil & Faraas & Fawas & Kayla & Laras & Radin & Zikri \\
\hline $\begin{array}{l}\text { Anak mempunyai inisiatif } \\
\text { dalam mengikuti } \\
\text { pembelajaran }\end{array}$ & 4 & 4 & 4 & 4 & 4 & 4 & 4 & 4 & 4 & 4 & 4 & 4 \\
\hline $\begin{array}{l}\text { Anak idealis dalam } \\
\text { pembelajaran }\end{array}$ & 3 & 3 & 3 & 3 & 3 & 4 & 3 & 3 & 3 & 3 & 3 & 3 \\
\hline $\begin{array}{l}\text { Anak berwawasan ke } \\
\text { depan (visioner) }\end{array}$ & 4 & 3 & 4 & 3 & 3 & 4 & 3 & 3 & 3 & 4 & 4 & 3 \\
\hline $\begin{array}{l}\text { Anak menunjukkan } \\
\text { sikap banyak akal }\end{array}$ & 4 & 4 & 4 & 4 & 4 & 4 & 4 & 4 & 4 & 4 & 4 & 4 \\
\hline Anak berfikiran terbuka & 4 & 3 & 4 & 4 & 4 & 4 & 4 & 4 & 3 & 4 & 4 & 4 \\
\hline Anak berfikiran kritis & 3 & 3 & 3 & 3 & 3 & 4 & 3 & 3 & 3 & 4 & 3 & 4 \\
\hline $\begin{array}{l}\text { Anak antusias dalam } \\
\text { pembelajaran }\end{array}$ & 4 & 4 & 4 & 4 & 4 & 4 & 4 & 4 & 4 & 4 & 4 & 4 \\
\hline $\begin{array}{l}\text { Anak memiliki rasa ingin } \\
\text { tahu }\end{array}$ & 4 & 4 & 4 & 4 & 4 & 4 & 4 & 4 & 4 & 4 & 4 & 4 \\
\hline Anak memiliki sikap ulet & 4 & 4 & 4 & 4 & 4 & 4 & 4 & 4 & 4 & 4 & 4 & 4 \\
\hline Anak berperilaku & 4 & 4 & 4 & 4 & 4 & 4 & 4 & 4 & 4 & 4 & 4 & 4 \\
\hline Anak peka & 4 & 4 & 3 & 3 & 4 & 4 & 3 & 4 & 3 & 4 & 3 & 4 \\
\hline Anak percaya diri & 4 & 3 & 4 & 4 & 4 & 4 & 4 & 4 & 3 & 4 & 4 & 4 \\
\hline Skor & 46 & 43 & 45 & 44 & 45 & 48 & 44 & 45 & 42 & 47 & 45 & 46 \\
\hline Max & 48 & 48 & 48 & 48 & 48 & 48 & 48 & 48 & 48 & 48 & 48 & 48 \\
\hline$\%$ & 95,83 & 89,58 & 93,75 & 91,67 & 93,75 & 100,00 & 91,67 & 93,75 & 87,50 & 97,92 & 93,75 & 95,83 \\
\hline Kriteria & $\begin{array}{c}\text { Sangat } \\
\text { tinggi }\end{array}$ & $\begin{array}{c}\text { Sangat } \\
\text { tinggi }\end{array}$ & $\begin{array}{c}\text { Sangat } \\
\text { tinggi }\end{array}$ & $\begin{array}{c}\text { Sangat } \\
\text { tinggi }\end{array}$ & $\begin{array}{c}\text { Sangat } \\
\text { tinggi }\end{array}$ & $\begin{array}{c}\text { Sangat } \\
\text { tinggi }\end{array}$ & $\begin{array}{c}\text { Sangat } \\
\text { tinggi }\end{array}$ & $\begin{array}{c}\text { Sangat } \\
\text { tinggi }\end{array}$ & $\begin{array}{c}\text { Sangat } \\
\text { tinggi }\end{array}$ & $\begin{array}{c}\text { Sangat } \\
\text { tinggi }\end{array}$ & $\begin{array}{c}\text { Sangat } \\
\text { tinggi }\end{array}$ & $\begin{array}{r}\text { Sangat } \\
\text { tinggi }\end{array}$ \\
\hline
\end{tabular}

Untuk lebih jelasnya dapat terlihat pada grafik di bawah ini:

Siklus III : Kreativitas anak

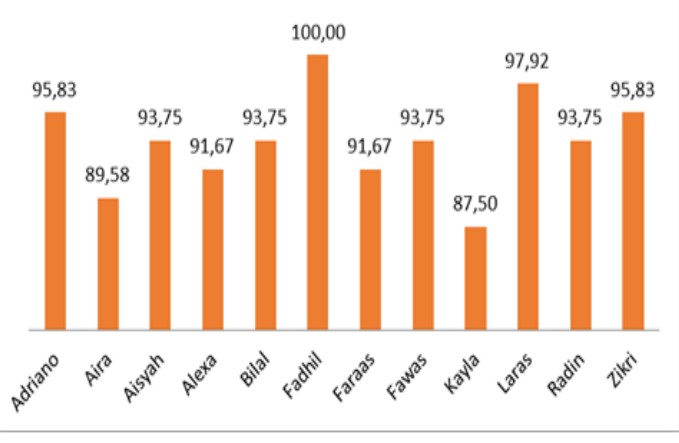

Grafik 7 Hasil Observasi

Kreativitas Siklus III

Dari hasil grafik $7 \mathrm{di}$ atas terlihat peningkatan kreativitas anak bila dibandingkan dengan tindakan pada siklus II. Anak semakin inisiatif dan visioner, hal ini bisa terlihat dari nilai observasi kreativitas anak yang pada saat siklus II sebesar 70,49\% meningkat menjadi 93,75\%. Dan bila dilihat pada tabel 8 di atas, Alhamdulillah kreatifitas semua anak sudah pada kategori sangat tinggi.

\section{SIMPULAN DAN SARAN Simpulan}

Berdasarkan deskripsi, analisis data, interpretasi dan pembahasan hasil penelitian tindakan "Upaya Meningkatkan Sikap Positif Belajar dan Kreativitas Anak melalui Pembelajaran Problem Solving di RA Al Isro Bogor" dapat disiimpulkan:

1. Pembelajaran Problem Solving dapat meningkatkan sikap positif belajar anak yang mencakup aspek; (1) antusias (2) rasa ingin tahu (3) berkonsentrasi dan (4) cermat (5) Menggunakan alat bantu dengan cepat (6) bersungguh-sungguh (7) fokus.

2. Pembelajaran Problem Solving dapat meningkatkan kreativitas anak yang mencakup aspek ; (1) berinisiatif (2) idealis (3) berwawasan ke depan /visioner (4) Banyak akal (5) berfikiran terbuka (6) berfikiran kritis (7) antusias (8) memiliki rasa ingin tahu (9) ulet (10) berperilaku 
spontan (11) peka dan (12) percaya diri .

\section{Saran}

Saran-saran yang dikemukakan terkait penelitian ini adalah sebagai berikut:

1. Guru

$\begin{array}{lr}\text { a. Dalam } & \text { penerapan } \\ \text { pembelajaran } & \text { Problem }\end{array}$ Solving dengan menggunakan media balok, guru dituntut untuk dapat mengoperasikan alat dan media yang digunakan seperti balok natural dan balok assesoris.

b. Dalam proses pembelajaran dituntut kreativitas guru untuk mengkombinasikan kegiatan memecahkan masalah dengan berbagai permainan yang dapat menunjang peningkatan kemampuan memecahkan masalah.

c. Hasil penelitian ini diharapkan dapat diterapkan di RA Al Isro karena selain meningkatkan sikap positif belajar, kegiatan ini juga dapat meningkatkan kreativitas anak dalam belajar.

2. Orang Tua

Keberhasilan pembelajaran di TK tidak lepas dari pengaruh dukungan orangtua dan keluarga. Oleh karena itu, orang tua siswa diharapkan memberikan dukungan terhadap perkembangan sikap positif belajar anak baik dengan menyediakan sarana-sarana bermain di rumah maupun membantu dan menemani anak ketika bermain di rumah.

3. Peneliti

Pembelajaran Problem Solving dengan menggunakan media balok tidak dapat dikatakan sebagai cara terbaik dalam meningkatkan sikap positif belajar anak, maka diharapkan penelitian ini dapat dijadikan bahan perbandingan bagi penelitian selanjutnya khususnya terkait dengan peningkatan sikap positif belajar dan kreativitas anak.

DAFTAR PUSTAKA

Abdul Majid, Pembelajaran Tematik

Terpadu, Bandung: Remaja

Rosdakarya, 2014.

Aisyah, Siti, Perkembangan dan

Konsep Dasar Pengembangan

Anak Usia Dini. Univesitas

Terbuka, Jakarta. 2010.

Ajzen, I, Attitude, Personality and Behavior Second Edition : England, Mc Graw-Hill

Anggani Sudono, Sumber Belajar dan Alat Permainan untuk Anak Usia Dini, Jakarta : PT. Grasindo, 2010.

Anita Yus, Model Pendidikan Anak

Usia Dini, Jakarta: Kencana Media Grup, 2011.

Augusta J. Evans.Inez: A Tale of

The Alamo Paperback-

August 30, 2015 by (Author)

Azwar Saifuddin, Sikap Manusia :

Teori dan Pengukurannya,

Yogyakarta : Pustaka Pelajar, 2011.

Azwar Saifuddin, Penyusunan Skala

Psikologi, Yogyakarta :

Pustaka Pelajar, 2008

Bukik Setiawan, Anak Bukan Kertas

Kosong: Panduan Eksplorasi,

Belajar, Berkarya di Zaman

Kreatif, Jakarta: Panda Media, 2015.

Christine Daymon, Metode-metode Riset Kualitatif dalam Publik

Relation dan Marketing Communikation, Yogyakarta: Bintang, 2008. 
Depdikbud, Program Kegiatan

Belajar Taman Kanak-Kanak, Jakarta : Depdikbud, 1994.

Emzir, Metodologi Penelitian pendidikan Kuantitatif \& Kualitatif , Jakarta: Raja Grafindo Persada, 2014.

Hamid Pattilama, Metode Penelitian Kualitatif, Bandung : Alfabeta, 2005.

Imam Machali, Kebijakan Perubahan

Kurikulum 2013 Dalam

Menyongsong Indonesia Emas

Tahun 2045, Jurnal Pendidikan Islam III no 1 (June 2014)

Jamal Ma'mur Asmani, Manajemen

Strategi Pendidikan Anak Usia

Dini, Yogyakarta: Diva

Press, 2009.

Kementrian Pendidikan dan

Kebudayaan, Pedoman

Pengelolaan Pembelajaran

PAUD, Jakarta: Direktoral

Jendral Pendidikan Anak Usia

Dini dan Pendidikan

Masyarakat, 2015.

Kementrian Pendidikan dan

Kebudayaan, Pedoman

Pengelolaan Pembelajaran
PAUD, Jakarta: Direktoral Jendral Pendidikan Anak Usia

Dini dan Pendidikan

Masyarakat, 2015.

Kuntjojo. Model - model

Pembelajaran. Jogjakarta: Raja

Grafindo Persada Buku Biru.

2010, hlm.

Wayan Nur Kancana dan Sumartana,

Evaluasi Pendidikan, (Surbaya:

Usaha nasional, 1986),hlm.275

Muhibbin Syah,Psikologi Pendidikan

Dengan Pendekatan Baru,

(Bandung: PT Remaja

Rosdakarya, 2004), hlm.135

Sarlito Wirawan,Pengantar Umum

Psikologi..., hlm.94

Gerungan Dipl, Psikologi Sosial..., hlm.163-164

S.C Utami Munandar, Mengembangkan Bakat dan Kreatifitas Anak Sekolah Petunjuk bagi Para Guru dan Orangtua, 1992, hal. 47

Yeni Rachmawati, Strategi Pengembangan Kreativitas pada Anak, hal. 7 